\title{
At læse Bourdieus "Kapitalen"
}

\author{
Loïc J. D. Wacquant \\ Professor i Sosiologi, Berkeley University of Califonia \\ loic@berkeley.edu
}

Af de mangfoldige arbejder af Pierre Bourdieu er The State Nobility måske det mest formidable og det mest paradoksale, og vil uden tvivl af netop disse grunde forvirre, om ikke forbløffe, mange af dens udenlandske læsere. For det første er det på en gang stædigt frankocentrisk i empirisk substans og omfang, og uimodståeligt universaliserende i analytisk hensigt og rækkevidde. For det andet, og dette er et af særkenderne ved Bourdieus sociologiske stil, er The State Nobility beslutsomt empirisk, data-ladet til en grad nær mætning, og alligevel besjælet af et kraftfuldt teoretisk projekt, som placerer det i epicenteret af debatterne om magt, kultur og fornuft ved århundredets afslutning.

I endnu højere grad end Distinction (Bourdieu, 1984), som den bygger på og udstrækker i et antal retninger, er dette studie af den sociale dominans's logik i avancerede samfund og af de mekanismer, hvorved det forklæder og foreviger sig selv, dybt forankret i det franske klasse-, kultur- og uddannelsessystems særegenheder i de to dekader der følger opstanden i maj 1968. Samtidig, som i enhver god etnologisk rapport ifølge Marcel Mauss, "det der kan forekomme som futile detaljer er faktisk en kondensering af principper" (Mauss, 1989, s. 7), er det Bourdieu hævder lige så operativt i andre lande og epoker.

\section{I}

Det $f \varnothing r s t e$ sådanne princip er det foruroligende og alligevel uoverstigelige forhold mellem sammenst $\varnothing \mathrm{d}$ og sammensværgelse, autonomi og medskyldighed, afstand og afhængighed, mellem materiel og symbolsk magt. Som Weber anførte det så godt, i enhver dominansstruktur er de "priviligerede gennem eksisterende politiske, sociale og økonomiske ordener" aldrig tilfredse med at udøve deres magt usmykket og at påtvinge deres fortrinsret nøgent. Hellere "ønsker [de] at se deres positioner transformeret fra rene faktuelle magtrelationer til et kosmos af opnåede rettigheder, og at vide at de på denne måde er indviede"(Gerth \& Wright Mills, 1946). I feudale samfund var kirken institutionen betroet at forvandle Herrens magt, funderet som den var på kontrol af våben, land og rigdomme, til guddommelig ret; gejstlig autoritet blev anvendt for at retfærdiggøre og derved fastholde den nye krigerklasses styre. I de komplekse samfund, den sene kapitalismes yngel, opretholder Bourdieu, har skolen overtaget dette arbejde med at indvi de sociale (arbejds-)delinger.

Denne tekst er en oversættelse af: Loïc Wacquant (1995), "Reading Bourdieu's 'Capital'", først publiceret i Bourdieu (1995), The State Nobility, Cambridge: Polity Press, s. ix-xxii. Teksten udg ør forordet til den engelske udgave af Bourdieu (1989), La Noblesse d'État. Morten Nørholm har oversat Loïc Waquants tekst til dansk.

Publisert: 01.01.2019

Praxeologi - Et kritisk refleksivt blikk på sosiale praktikker (C2019 Loïc J. D. Waquant

DOI: http://dx.doi.org/10.15845/praxeologi.v1i0.2597 
Således at ikke én men to kapital-arter nu giver adgang til magtpositioner, definerer strukturen af det sociale rum og styrer gruppers og individers livschancer og livsbaner: $\varnothing$ konomisk og kulturel kapital.

Akkreditiver hjælper med til at definere den samtidige sociale orden, i den middelalderlige forståelse af ordo, et sæt af graderinger på samme tid verdslige og åndelige, jordiske og himmelske, som etablerer usammenlignelige grader af værd blandt mænd og kvinder, ikke kun ved at sortere og allokere dem på tværs af de forskellige rangfølger der udgør den sociale struktur, men også, og mere vigtigt, ved at præsentere de resulterende uligheder mellem dem som uundgåelige nødvendigheder, $f ø \mathrm{dt}$ af den enkeltes talent, flid og ønske. Dette fordi kulturel kapital, skønt først og fremmest akkumuleret og vidregivet i familien, forekommer at høre uløseligt til ihændehaverens person. Det faktum at det "lykkes at kombinere prestigen ved medfødt ejendom med tilegnelsens merit" (Bourdieu, 1986, s. 245) gør den enestående tilpasset til at legitimere den fortsatte arv af sociale privilegier i samfund, forlokket af det demokratiske ideal.

Her er Bourdieus objekt den sociale alkymis operationer, hvorved et socialt hierarki forstiller sig, ikke mindre over for for dem det udmærker end over for dem det udelukker, som en skala for menneskeligt fortrin, hvordan en historisk vilkårlig social orden, forankret i den politiske og $\emptyset$ konomiske magts materialitet, omdanner sig til det der stiller ethvert intelligens-aristokratis ydre fremtoning til skue. Fra denne synsvinkel er tildelingen af en elite-grad ikke så meget et "overgangsritual", à la Van Gennep, som det er et "instituerings-ritual" (Bourdieu, 1990a): Det markerer ikke et før og efter så meget som det udskiller - og ophøjer - de der er bestemt til at optage højtstående sociale positioner fra dem over hvem de vil herske. Den vækker reverens for og indvier dem, i den stærkeste forståelse af ordet, dvs den gør dem hellige (enhver der har deltaget i dimissionsfesten på et større britisk eller amerikansk universitet kan ikke andet end blive slået af deres arkaisk religiøse fornemmelse, som ville have glædet Robertson Smith). Ordet akkreditivers, engelsk "credentials", latin credentialis, etymologi, at tilføje autoritet (afledt i sin tur fra credere at tro), vidner om, at tildelingen af et diplom er højdepunktet i en lang produktionscyklus af kollektiv tro på legitimiteten i en ny form for klasseherredømme.

\section{II}

Ganske rigtigt, hvor meget end "generaliseringen af ridderslags-ceremonien" ifølge Marc Bloch var "symptomet på en dybtgående forandring af begrebet ridderskab" i middelalderen (Bloch, 1968), så argumenterer Bourdieu for, at generaliseringen af uddannelsesmæssige titler som forudsætning for opstigningen til toppen af private selskaber og offentlige bureaukratier signalerer konsolideringen af en ny dominansform og en korresponderende forandring i det system af strategier, hvorved den herskende klasse opretholder og maskerer sig på bekostning af rask og kontinuerlig selvmetamorfose.

I feudalt samfund antog forholdet mellem den verdslige og den åndelige magtpol formen af en relativt enkel, dualistisk og alligevel komplementær modsætning mellem krigere og præster, militært og hierokratisk autoritet, sværdets og åndens stridsmænd. Med konstitueringen af den formelt rationelle stat og den "anden kapital"s samtidige overlegenhed (de to, er det Bourdieus hypotese, er korrelative historiske opfindelser), erstattes dette modsætningsfyldte par med et overordentligt komplekst spind af sammenkædninger på kryds og tværs mellem den mangfoldighed af felter, hvor de forskellige, nu effektive, former for social magt cirkulerer og koncentrerer sig. Den kæde af indbyrdes afhængigheder, som væver dem sammen i denne underlige helhed, kalder Bourdieu magtfeltet - field of power - (et begreb introduceret i de tidlige 1970-ere men for første gang her både teoretisk og empirisk udviklet) rækker fra det $\varnothing$ konomiske felt i den ene ende til feltet af kulturel produktion i den anden (Bourdieu, 1971)1. Industrialist og kunstner i det nittende

\footnotetext{
${ }^{1}$ Det mere generelle begreb felt (champ) diskuteres syntetisk i Bourdieu (1993a). For uddybninger og eksemplariske illustrationer se Bourdieu (1993b).
} 
århundrede, chef og intellektuel i det tyvende, er, i Frankrigs tilfælde, personificeringerne af henholdsvis den dominerende og den dominerede pol i magtfeltet. Mellem dem, og i symmetrisk og omvendt orden i overensstemmelse med den relative overlegenhed de tildeler $\varnothing$ konomisk eller kulturel kapital, er det politiske felt, feltet af højere offentlig administration, erhvervenes felt og universitetsfeltet opstillet.

Som kapital-arterne varierer og autonome felter forøges - to foretagender der ifølge Bourdieu er ækvivalente begrebslige oversættelser af den samme epokale trend, idet kapital og felt gensidigt definerer og specificerer hinanden - og som den mere gennemsigtige "mekaniske solidaritet" mellem svagt differentierede og udskiftelige magte viger for den mere komplicerede "organiske solidaritet" mellem meget tydeligt adskilte og forskelligartede magte, stiger spændingerne og konflikter truer med at bryde ud. For det faktum at forskelligartede former for kapital nu træder ind i dominansformlen, implicerer at forskellige principper for social forrang og legitimitet skal tages i betragtning og forliges. Magtfeltet er præcis denne arena, hvor besiddere af forskellige slags kapital konkurrerer om hvem af dem der vil sejre. På spil i disse kampe mellem de dominante (ofte forvekslet med konfrontationer mellem herskende og underordnet klasse) er den relative værdi og styrke af rivaliserende udgaver af kapital, som i særdeleshed fastsættes af den aktuelle "vekselkurs" for $\varnothing$ konomiske og kulturelle valutaer.

Det er her systemet af elite-etablissementer inden for højere uddannelse kommer ind i billedet. I samfund karakteriseret ved den samtidige tilstedeværelse af og konkurence mellem diverse former for magt, der alle i stigende grad er afhængige af forvandlingen til akkreditiver som et middel til selvforevigelse, ikke alene garanterer dette system fortrinsberettiget og hurtig adgang til ledende positioner til sønnerne af de slægter der allerede har monopol på dem (fuldt medlemsskab af adelen, hvad enten det baserer sig på blod eller diplomer, er essentielt en mandlig affære). Dets høje grad af autonomi og intern differentiering i overensstemmelse med den samme antinomi mellem penge og kultur som organiserer magtfeltet i almindelighed, sætter det også i stand til at desarmere konflikter inden for grupperne ved at anerkende og præmiere diverse krav på skolastisk, og dvs social excellence.

"Intellektuelle skoler" som École normale supérieure, frøbedet for Frankrigs høj-intelligentsia (Bourdieu er en af en lang rad af distingverede alumner), drager og ærer hovedsageligt de studerende som er stærkest tiltrukket af dem i første omgang fordi deres dispositioner er levende forkropsligg ørelser af den slags kapital, disse skoler kræver og valoriserer, nemlig børn der stammer fra de kultiverede fraktioner af borgerskabet, hvortil de prompte vender tilbage. Etablissementer gearet til at skole industri- og ejendomsledere, såsom École des hautes études commerciales og École polytechnique er først og fremmest af interesse for studenter, der kommer fra og er bestemt for de $\emptyset$ konomisk rige fraktioner af det franske højere borgerskab. Placeret midt i mellem de to poler af franske eliteskoler blander École nationale d'administration, hvorfra kabinetmedlemmer og højere statstjenestemænd kommer, de to slags kompetencer, kulturel og økonomisk, og rekrutterer studenter hvis familie-fædrenearv typisk kumulerer sjældne akkreditiver og gammel rigdom.

Ved at tilbyde adskilte baner for videregivelse af privilegier og ved at anerkende konkurrerende, og ovenikøbet modsatrettede, krav på forrang inden for dets egen orden, isolerer og beroliger de forskellige kategorier af arvinger af magt, og sikrer, bedre end nogen anden indretning, pax dominorum uundværlig for delingen af hegemoniets bytte. Derfor er det ikke det ene eller det andet etablissement, men feltet (dvs rummet af objektive relationer) de udgør, som bidrager qua felt til reproduktionen af den evolverende matrix af mønstrede forskelle og afstande bestemmende for den sociale orden. Det umiddelbare, konkrete, objekt for The State Nobility er strukturen og funktionen af det $\emptyset$ verste bånd i Frankrigs system af højere uddannelse og dets koblinger til dette lands borgerskab og top-selskaber. Dets dybere, teoretiske, mål er at udvikle, i den selvsamme bevægelse hvorved det empirisk udstiller en af dets historiske samtidigheder, en model af den sociale dominansarbejdsdeling, som hersker i avancerede samfund, hvor en diversitet af magtformer sameksisterer og kappes om overlegenhed. 


\section{III}

Dets ekstreme centralisering og høje sociale selektivitet, forankret i mangeårige bånd mellem klassekløfter, stats-opbygning, republikanisme og uddannelse og i tvedelingen mellem universitet og grandes écoles, den iver hvormed det indvier verdslig (dvs borgerlige, bourgeois) kulturel bagage og den korresponderende brutalitet hvormed det nedvurderer dets egne produkter som "scolaires", gør alt sammen Frankrigs system af højere læring til et fordelagtigt terræn at udstille den hemmelige korrelation mellem akademisk og social klassifikation og den janus-hovedede gruppe af medvidengennem-konflikt mellem magtfeltets to poler på. Specificiteten af disse empiriske materialer må på den anden side ikke bortlede opmærksomheden fra den bredere anvendelighed af den analytiske ramme beskæftiget med at behandle dem. Ordentligt udlagt tilbyder The State Nobility et systematisk program til undersøgelser af ethvert nationalt magtfelt, forudsat at den amerikanske (britiske, japanske, brasilianske etc) læser udfører det omformningsarbejde, nødvendigt for, ved homologisk ræsonnering, at generere et organiseret sæt af hypoteser til sammenlignende unders $\varnothing$ gelse i sit eget hjemland. ${ }^{2}$

Bourdieu hævder at den chiastiske organisering af den samtidige herskende klasse, der udtrykker det historiske stade i arbejdsdelingen mellem materiel (økonomisk) og symbolsk (kulturel) kapital, og dens projektion på feltet af eliteskoler, der både løsner sig fra og omklamrer de to, er karakteristisk for alle avancerede samfund. Men denne underjordiske modsætningsstruktur antager fænomenalt diverse former i forskellige lande, afhængig af et antal krydsende faktorer, inklusive (over-)klassens formations, statsstrukturers og uddannelsessystemets udformnings historiske livsbane i det samfund og på det tidspunkt under overvejelse. På samme måde foreslår Bourdieu, at den "ny kapital"s rejsning overalt oversættes til et skift af reproduktionsmåder, fra direkte reproduktion, hvor magt essentielt overføres inden for familien via økonomisk ejendom, til skole-formidlet reproduktion, hvor testamenteringen af privilegier samtidigt effektueres og forvandles ved uddannelsesinstitutioners mellemkomst. Men, igen, alle herskende klasser tyer til begge måder samtidig (Bourdieu understreger udtrykkeligt at den stigende relative vægt af kulturel kapital ikke på nogen måde påvirker den økonomiske kapitals evne til at formere sig autonomt) og deres partielle præference for den ene eller den anden afhænger af hele systemet af reproduktionsinstrumenter til deres rådighed og af den aktuelle magtbalance mellem de forskellige fraktioner, bundet til denne eller hin overførselsmåde.

Det følger, at det ville være en fejltagelse - Alfred North Whitehead kaldte det den "fejlplacerede konkretheds vildfarelse" (Whitehead, 1948, s. 52) - at lede efter én-til-én korrespondenser på tværs af landegrænser mellem de institutioner, det er betroet at forevige netværket af magtpositioner $\mathrm{i}$ forskellige samfund ( $f x$ at søge en nøjagtig amerikansk eller britisk modpart til École nationale d'administration, til hvilken der ingen findes). Man skal hellere, idet man anvender den relationelle tænkemåde indeholdt i begrebet felt, sætte sig for i hver enkelt specielle tilfælde at afdække empirisk de specifikke konfigurationer antaget af det kompleks af modsætninger, der strukturerer socialt rum, uddannelsessystemet og magtfeltet, såvel som deres indbyrdes forbindelser.

For at illustrere det summarisk: Strukturen i rummet af eliteuddannelser drejer sig, i det franske tilfælde, om en skarp horisontal dualisme mellem grandes écoles (udvalgte "graduate schools", højere læreanstalter, baseret på et antal klausuler, særlige forberedelsesklasser og nationale, konkurrenceprægede adgangsaksamener med direkte vej til høj profil-jobs) og universitet (masseinstitutioner åbne for alle der fuldfører deres "secondary cursus", tager studentereksamen, og kun Iøst tilknyttet beskæftigelses-verdenen) og, inden for feltet af grandes écoles selv, mellem, langs den ene akse st $\varnothing$ rre og mindre skoler og langs den anden akse etablissementer orienteret mod intellektuelle værdier og etablissementer rettet mod økonomisk-politiske positioner. I det decentraliserede amerikanske uddannelsessystem er disse dualiteter brudt op i en hel serie af

\footnotetext{
${ }^{2}$ For en beslægtet diskussion af det forførende ved ideografisk reduktion hvad angår Bourdieus analyse af det franske universitetsfelt, se Wacquant (1990).
} 
indskudte modsætninger, vertikale såvel som horisontale: Mellem private og offentlige sektorer (begyndende på, "level of secondary schooling", mellemskole-niveau), mellem "community college", seminarier o.l., og fireårige universiteter og mellem et stort antal "tertiære" uddannelsesinstitutioner og en håndfuld elite-etablissementer (forankret $i$ the Ivy League), der tiltvinger sig broderparten af kommandoposterne i såvel det private som i det offentlige. På grund af den økonomiske kapitals dybt rodfæstede, historiske overlegenhed over kulturel kapital, udmønter modsætningen mellem de to magtpoler og mellem de korresponderende fraktioner af den amerikanske herskende klasse sig ikke i form af rivaliserende spor eller skoler. I stedet projiceres den inden for hvert (elite-)universitet i de modsætnings- og spændingsfyldte forhold mellem den gradvise adskillelse af "arts and sciences", humaniora og naturvidenskab, på den ene side, og "professional schools", professions-skoler (især jura, medicin og handel) på den anden, såvel som de direkte modsatte forhold disse udviser til magten-der-kommer og i de kontrasterende billeder af viden de påberåber sig (forskning versus service, kritik versus ekspertise, kreativitet versus anvendelse etc).

Alligevel, på trods af forskellene i deres respektive systemiske placering og kredsløb, fungerer Ivy League's universiteters og private kostskolers tæt integrerede netværk som en nær, omend delvis, analog til det franske system af grandes écoles og deres associerede classes préparatoires, forberedelsesklasser. I og med "blot påstanden om at eliteskoler eksisterer, især sociale eliteskoler, går imod det inderste amerikanske væsen" (Cookson \& Persell, 1985, s.15) ${ }^{3}$, er det måske ikke overflødigt ganske kort at genkalde sig præcis hvor eksklusive - og ekskluderende - de sidste er. Det er tilstrækkeligt at notere sig, at så godt som alle kandidater fra USA's bedste kostskoler (der udgør $1 \%$ af amerikansk "high-school"-indskrivning) optages på "college", videregående uddannelser, sammenlignet med $76 \%$ af de studerende fra katolske og andre private skoler og $45 \%$ af alle "public school seniors", afgående fra offentlige skoler. Disse overpriviligerede studerende, hvoraf ni ud af ti er børn af liberale erhvervsdrivende eller chefer inden for handel og industri (to tredjedele af deres fædre og en tredjedel af deres mødre gik på "graduate", eller "professional schools", højere læreanstalter eller professions-skoler) har også større sandsynlighed for at lande på de højst vurderede "campuses", universitetsområder, også selvom deres resultater ved skoleegnethedsprøver kontrolleres: I 1982 ansøgte næsten halvdelen af de afgående "preppies" Ivy League-skoler og $42 \%$ heraf blev optaget mod $26 \%$ af alle kandidater landet over (selvom de sidste er taget fra de $\emptyset$ verste $4 \%$ af landets studerende) takket være tætte organisatoriske bånd og aktive rekrutteringskanaler mellem kostskoler og højstatus private "colleges", højere læreanstalter (Cookson \& Persell, 1985).

I 1984 havde blot tretten elite-kostskoler uddannet $10 \%$ af større U.S.-aktieselskabers bestyrelsesmedlemmer og omtrent en femtedel af lederne af to større firmaer, ligesom kombinationen af en grad fra et eksklusivt college og en overklasseherkomst mangedobler sandsynligheden for at blive en del af bestyrelsesmagtens "inderkreds". Blandt højere ledere samarbejder besiddelsen af prestigegivende uddannelsesakkreditiver og overklasse-oprindelse om at bestemme, hvem der bliver administrerende direkt $\varnothing r$, medlem af udenlandske firmaers bestyrelser eller træder ind i større aktieselskabers direktion. Og ligesom diplomer der sanktionerer "generaliseret bureaukratisk kultur" tenderer mod at fortrænge formaliserede tekniske færdigheder i Frankrig, giver en juridisk top-eksamen eller en bachelorgrad fra et udvalgt privat college i USA en leder større chance for at nå til ansvarlighedens top i aktieselskabsverdenen end en kandidatgrad fra et højtrangerende MBA-program (Useem \& Karabel, 1986).

Kandidater fra elite-kostskoler og -universiteter, der kommer fra velstående familier opstillet $\mathrm{i}$ The Social Register er også massivt overrepræsenteret i den amerikanske stats $\emptyset$ verste lag (inklusive kabinettet, retsvæsenet og regeringens rådgivende forsamlinger), politiske embedsmænd, dyre advokatfirmaer, de nationale medier, filantropiske organisationer og de skønne kunster (jf. Useem, 1984; Cookson \& Persell, 1985, s. 198-202; Schwartz, 1987; Marcus, 1991; Domhoff, 1993; Levine,

\footnotetext{
${ }^{3}$ De talværdier der følger er også uddrag af dette fortræffelige studie.
} 
1980 og for et historisk perspektiv Baltzell, 1989). Det skal videre bemærkes, at god tro-medlemsskab af det amerikanske magtfelt via eliteuddannelse fortsætter med at være begrænset til den hvide kaste (jf. Zweigenhaft \& Domhoff, 1991). Og de der dukker ud af lektielæsningens smeltedigel og bliver "super-vekselerere" i Boston, Washington og L.A. føler sig ikke mindre berettigede til deres positioner og prærogativer end deres modstykker fra rue Saint-Guillaume i Paris.

\section{IV}

At skelne mellem de (specifikke) empiriske fund og den (generelle) teoretiske model indeholdt i The State Nobility foreslår en dagsorden for en sammenlignende, genetisk og strukturel sociologi af nationale magtfelter, som for hvert samfund ville katalogisere effektive kapitalformer, specificere deres differentieringsgrads, afstands og modsætnings sociale og historiske determinanter, og evaluere den rolle systemet af eliteskoler (eller funktionelt ækvivalente institutioner) spiller $\mathrm{i}$ reguleringen af de forhold, de udviser.

En sådan unders $\varnothing$ gelse ville uden tvivl bekræfte, at den skoleoverførte reproduktionsmådes større uigennemskuelighed, og derved dens forøgede kapacitet til at forstille forevigelsen af magt, opnås med store omkostninger. For det første bliver det mere og mere omkostningsfyldt at være en arving: Overalt underkaster eliteskoler deres studerende strenge arbejdsregimenter, spartanske livsstile og sociale og intellektuelle ydmygelses-praktikker, der indebærer betydelige personlige ofre. For det andet er den stokastiske logik, der nu styrer overførslen af privilegier sådan, at, selvom han nyder ethvert muligt fortrin fra begyndelsen, er ikke enhver leders, kirurgs eller videnskabsmands s $\varnothing n$ sikret at opnå en sammenlignelig fremstående social position ved løbets afslutning ${ }^{4}$. Den skoleformidlede reproduktionsmådes specifikke modsætning ligger præcist i den adskillelse den skaber mellem den kollektive klasseinteresse, som eliteskolefeltet sikrer, og interessen hos de af dets enkeltmedlemmer, det uafvendleligt må afvise for at gøre det.

Bourdieu hævder, at en gruppe overklasse-unges (begrænsede) nedadgående mobilitet og de tværgående, "afvigende baner" der flytter et antal af dem fra den ene af magtfeltets poler til den anden - som når afkom fra den kulturerede del af borgerskabet får adgang til poster med selskabs- eller politisk ansvar - er magtfulde kilder til ændringer inden for magtfeltet såvel som vigtige bidragydere til de "nye sociale bevægelser", der er blomstret op i den universelle akademiske konkurrences tidsalder. Under alle omstændigheder er ikke alle arvinger, under dette regimente, både i stand til og begærlige efter at lægge skuldre til successionens byrder.

Det betyder, at for at realisere sig selv fuldt ud, kan en magtens mangfoldige logikkers generative sociologi ikke begrænse sig til at tegne en objektivistisk topologi over kapitalens fordelinger. Den skal i sig selv omfatte den "specielle psykologi", som Durkheim kaldte på men aldrig leverede ${ }^{5}$. Den skal, derfor, yde fuld forklaring på den sociale genese og implementering af de tanke- og handlingskategorier, gennem hvilke deltagerne i de forskellige sociale verdner under unders $\emptyset$ gelse kommer til at opfatte og aktualisere (eller ikke) de potentialiteter de besidder. For Bourdieu er en sådan dissektion af individernes praktiske erkendelse absolut nødvendig, fordi sociale strategier aldrig ensidigt determineres af strukturens objektive tvange, lige så lidt som af agentens subjektive intentioner. Snarere affødes praktikken i det gensidige krav fra position og disposition i det nu

\footnotetext{
${ }^{4}$ Cookson og Persell understreger, at fittet mellem "kostskolegang og adgang til elite-cirkler" er alt andet end perfekt (1985, s. 204ff) og indicerer at børn fra den amerikanske herskende klasse i stigende grad er uvillige til at udstå den selv-fornægtelse, isolation, psykiske smerte og voldsomme all-round livsaskese, som arven af magt fremover kræver. Ikke så få af dem forlader "prep school", private forberedelsesskoler (eller relegeres fra dem), forsøger at begå selvmord eller vælger simpelthen at forfølge andre, mindre kritiske beskæftigelser.

5 "Vi fastholder, at sociologi ikke fuldstændig har nået sit mål, så længe det ikke er trængt ind i individets inderste sind (le for intérieur) for at relatere de institutioner den søger at forklare til deres psykologiske betingelser" (Durkheim, 1909, s. 755).
} 
harmoniske, nu ikke-harmoniske møde mellem "sociale strukturer og mentale strukturer", historie, "fortingsliggjort" som felter og historie "forkropsliggjort" i form af denne socialt mønstrede matrix af præferencer og tilbøjeligheder, som konstituerer habitus ${ }^{6}$.

Det er derfor, at The State Nobility åbner med en analyse af de praktiske taxonomier og aktiviteter, gennem hvilke lærere og studerende i fællig producerer de franske eliteskolers hverdagsvirkelighed som en meningsfuld Lebenswelt. I Part I ("Misrecognition and Symbolic Violence") fører Bourdieu os ind i sjælen på en filosofiprofessor på École normale supérieure, så vi kan lære at tænke, føle og dømme som én og derved opfatte som indefra, som var det indlysende, nav-

lestrengsforholdet - der alligevel kontinuert benægtes - mellem akademisk excellence og klassedistinktion. Og i Part II ("Ordination") rekonstruerer han med smertefuld præcision og patos de quasi-magiske adskillelses- og samlings-handlinger, hvorved den skolastiske adel forenes i krop cum sjæl og gennemsyres af den yderste vished om dens sociale missions retfærdighed. Den omhyggelige (gen)skabelse af selvet, involveret i fabrikationen af de dominantes habitus, afslører hvordan magt sniger sig ind ved at forme sjæle og præge attrå indefra, lige så meget som udefra, gennem de materielle betingelsers "sløve tvangstanke".

Langt fra at løse sig i det mekaniske samspil mellem homologe strukturer (og i andenordens korrespondenser mellem homologier, der opererer på forskellige niveauer i magtfeltet og de konstituente underfelter) er Bourdieu i stand til at vise, at domination opstår i og gennem de særlige forhold af u-middelbare og infra-bevidste "fit" mellem struktur og agent, der opstår når som helst enkeltindivider konstruerer den sociale verden v.h.a. visionsprincipper, der, idet de kommer fra denne verden, er mønstret efter dennes objektive delinger. Således kan de på en og samme tid og uden modsigelse bekræfte, at sociale agenter er fuldt determinerede og fuldt determinerende (og derved opløses det skolastiske alternativ mellem struktur og ageren).

Med en parafrase over Marx's berømte formulering, kan man sige, at for Bourdieu, skaber mænd og kvinder deres egen historie, men de skaber den ikke i kategorier efter eget valg. Og vi kan også, uden at ligge under for ideealisme, sige, at social orden dybest set er en gnoseologisk orden, forudsat at vi samtidig anerkender, at de kognitive skemata gennem hvilken vi kender, oversætter og aktivt samler vores verden selv er sociale konstrukter, der inde i de individuelle kroppe transskriberer de tvange og lettelser fra det miljø de stammer fra.

\section{V}

Man kan måske blive forvirret af det faktum, at officielle statsstrukturer, -politikker og -personel - det faste inventar i konventionelle sociologier af staten - stort set ikke dukker op i denne bog. Dette velovervejede fravær er beregnet på at dramatisere et af Bourdieus nøgleargumenter: At staten ikke nødvendigvis er der hvor vi leder efter den (dvs hvor den tavst instruerer os $\mathrm{i}$ at kaste vort blik og net) eller, mere præcist, at dens virkningsfylde og effekter kan være stærkest nøjagtigt når og hvor vi hverken forventer eller mistænker dem. ${ }^{7}$

For Bourdieu ligger det særlige kendetegn for staten som en organisation, $f \varnothing \mathrm{dt}$ af og gearet til koncentrationen af magt(e), ikke der hvor materialistiske teorier fra Max Weber over Norbert Elias til Charles Tilly typisk placerer det. Vi forbliver alt for forelskede i et (attende århundredes-) syn på staten som en "toldopkrævende og rekrutterende sergent", når vi i den ser den ageren, der succesfuldt monopoliserer legitim fysisk vold og undlader samtidig at notere at den også, og mere

\footnotetext{
${ }^{6}$ For en mere fyldestgørende diskussion af dette tovejs-forhold mellem habitus og felt se Bourdieu \& Wacquant (1992, s. 12-19 og s. 97-140).

${ }^{7}$ I dette er Bourdieu enig med den afd $\varnothing$ de Philip Abrams, som i Abrams (1988, s. 58-89) understregede, at en af hovedforhindringerne for en sociologi af staten ligger i den specielle evne staten har til at skjule sin egen magt.
} 
beslutsomt, monopoliserer legitim symbolsk vold. ${ }^{8}$ Staten, antyder Pierre Bourdieu, er først og fremmest den "centralbank for symbolsk kredit", der garanterer alle nominationshandlinger, hvorved sociale delinger og ophøjelser tildeles og bekendtgøres, dvs forkyndt som universelt gyldige inden for et givent territoriums og en given befolknings kompetenceområde. Og den akademiske titel er den paradigmatiske manifestation af denne "stats-magi", hvorved sociale identiteter og skæbner fremstilles under dække af at blive registreret, social og teknisk kompetence sammensmeltes og overdrevne privilegier omdannes til retmæssige rettigheder.

Statens vold ud $\varnothing$ ves altså ikke alene (og ikke en gang hovedsageligt) over for de underordnede, de gale, de syge og de kriminelle. Det angår os alle, på myriader af ubetydelige og usynlige måder, hver gang vi erfarer og konstruerer den sociale verden, efter kategorier, indpodet os via vores uddannelse. Staten er ikke kun "derude" i form af bureaukratier, autoriteter og ceremonier. Den er også "herinde", uudsletteligt indgraveret i os, lejret i vores tilværelses fortrolighed i de fælles måder, hvorpå vi føler, tænker og bedømmer. Ikke hæren, anstalten, hospitalet eller fængslet, men skolen er statens mest magtfulde kanal og tjener.

Durkheim var på rette vej da han, som den gode kantianer han var, beskrev staten som en "social hjerne" hvis "essentielle funktion er at tænke", et " særligt organ, betroet at udarbejde bestemte repræsentationer af værdi for kollektivet" (Durkheim, 1950, s. 89; 87). Men disse repræsentationer, insisterer Bourdieu, tilhører det klassedelte samfund, ikke en forenet og harmonisk social organisme, og accepten af dem er produktet af snigende påtvingning, ikke spontan gensidig overenskomst. Ulig totemistiske myter er de "skolastiske klassifikationsformer", som udg ør grundlaget for den logiske integration af avancerede nationer, klasseideologier, der tjener særlige interesser i selve den bevægelse hvorved de skildrer dem som universelle. Den sociale realitets videns- og konstruktionsinstrumenter, udspredt og indprentet af skolen, er også, og uundgåeligt, instrumenter til symbolsk dominans. Og således er det, at den akkreditiv-baserede adel står i gæld for den troskab vi viser den, til det faktum, at de "fortolknings-rammer" som staten skaber og påtvinger os gennem skolen, for at låne et andet af Kenneths Burkes udtryk, udgør så mange "accept-rammer" (Burke, 1984), der får os til blidt at bøje os under et åg vi ikke en gang bemærker.

\section{VI}

Ved at tilbyde først en anatomi af produktionen af den ny kapital og dernæst en analyse af de sociale effekter af dens cirkulation i de forskellige felter der deltager i dominations-arbejdet, afslører The State Nobility hvad Bourdieus "uddannelses-"sociologi virkelig er og hvad den har været fra begyndelsen: En generativ antropologi af magte, fokuseret på det specielle bidrag, symbolske former yder til disses virkning, omdannelse og naturalisering. Lige så meget som den klassiske sociologis grundlæggeres triumvirat var stærkt optaget af religionen som den spirende kapitalistiske modernitets opium, moralske lim og teodice, stammer Bourdieus vedvarende interesse i skolen fra den rolle han tildeler den som garant for den samtidige sociale orden, via den stats-magi der indvier sociale delinger ved samtidig at indskrive dem i materielle fordelingers objektivitet og kognitive klassifikationers subjektivitet.

Webers advarsel om at "patenter på uddannelse vil skabe en priviligeret 'kaste'" har vist sig at være forudvidende: De teknokrater der står i spidsen for dagens kapitalistiske firmaer og regeringskontorer har til deres rådighed alt hvad der hører sig til af magte og titler - af ejendom, uddannelse og herkomst - uden historisk fortilfælde. De behøver ikke vælge mellem fødsel og fortjeneste, tilskrivelse og præstation, arv og umage, traditionens aura og modernitetens effektivitet, for de kan favne dem alle. Og alligevel fordømmer Bourdieus sobre diagnose af statsadelens - the state nobility's - komme os hverken til kynisme og passivitet eller til den "kulturpolitiske" retoriks

\footnotetext{
${ }^{8}$ Ganske rigtigt kan man argumentere for at staten må have indfanget en stor del symbolsk vold hvis den nogensinde skal kunne etablere legitimiteten i dens anvendelse af tvang.
} 
falske radikalisme. For den relative autonomi, den symbolske magt nødvendigvis må besidde for at udfylde sin legitimerende funktion medfører altid muligheden for dens afledning til tjeneste for andre mål end reproduktion. Dette er i særdeleshed sandt når "legitimations-kæden" vokser stedse mere udstrakt og indviklet, og når dominansen udøves i fornuftens, universalitetens og almenvellets navn.

Fornuft, argumenterer Bourdieu idet han driver historicistisk rationalisme til dens grænse, er hverken en nietzschesk illusionists trick, næret af "viljen til magt", eller en antropologisk konstant, forankret i menneskelig kommunikations immenente struktur, som hos Habermas, men en kraftfuld og dog skrøbelig historisk opfindelse, født af mangfoldiggørelsen af de sociale mikrokosmosser, såsom videnskabs, kunsts, juras og politiks felt, hvori universelle værdier kan realiseres, omend imperfekt (Bourdieu, 1990b, 1994b, især s. 161-167) ${ }^{9}$. At et stedse st $\varnothing$ rre antal hovedpersoner i spillet om dominans finder det $n \varnothing d v e n d i g t$ at opdigte rationelle retfærdigg $\varnothing$ relser for deres handlinger, øger paradoksalt nok chancen for at de fremmer, til trods for dem selv, fornuftens fremmarch.

At lege med universalitet er at lege med ild. Og de intellektuelles kollektive rolle som bærere af det "universelles korporatisme" er at tvinge verdslige magte til at leve op til, og påtvinge hverandre, selve de fornufts-normer de påkalder, uanset hvor hyklerisk. Dette sætter videnskab - og i særdeleshed socialvidenskab - i vor tids kampes epicenter. For jo mere videnskaben samles af de dominante på vegne af deres herredømme, desto mere afgørende er det for de dominerede at benytte sig af dens resultater og instrumenter. Dette er den politiske betydning af og det politiske formål med The State Nobility: At bidrage til denne rationelle viden om dominans, som, non obstante de postmoderne profeters udmattede jeremiader, forbliver vort bedste våben mod dominansens rationalisering.

\section{Referencer}

Abrams, P. (1988). Notes on the Difficulty of Studying the State. Journal of Historical Sociology, 1 (1), s. 58-89.

Baltzell, E.D. (1989). Philadelphia Gentlemen: The Making of a National Upper Class. New Brunswick: Transaction Press.

Bloch, M. (1968). La société féodale. Paris: Albin Michel. Originaludgaven er fra 1930.

Bourdieu, P. (1995). The State Nobility. Cambridge: Polity Press.

Bourdieu, P. (1994a). Rethinking the State: On the Genesis and Structure of the Bureaucratic Field. Sociological Theory, 12 (1), s. 1-19.

Bourdieu, P. (1994b). Un acte désintéressé est-il possible? I Raisons pratiques. Paris: Éditions du Seuil.

Bourdieu, P. (1993a). Some Properties of Field. I Sociology in Question, London og Newbury Park: Sage Publications.

Bourdieu, P. (1993b). The Field of Cultural Production. Cambridge: Polity Press og New York: Columbia University Press.

Bourdieu, P. (1990a). Rites of institution. I Language and Symbolic Power, Cambridge: Polity Press, og Cambridge: Harvard University Press, s. 117-127.

Bourdieu, P. (1990b). The Scholastic Point of View. Cultural Anthropology, 5. november, s. 380-391.

Bourdieu, P. (1989). La noblesse d'Etat. Grandes écoles et esprit de corps. Paris: Éditions de Minuit.

Bourdieu, P. (1986). Forms of Capital. I Richardson, J. G. (Red.), Handbook of Theory and Research for the Sociology of Education (s. 245). New York: Greenwood Press.

Bourdieu, P. (1984). Distinction. A Social Critique of the Judgement of Taste. Cambridge: Harvard University Press.

\footnotetext{
${ }^{9}$ For to stimulerende fortolkninger af Bourdieus foreslåede "tredje vej" mellem modernistisk rationalisme og postmoderne relativisme se Calhoun (1995) og Harrison (1993).
} 
Bourdieu, P. (1971). Champ du poivoir, champ intellectuelle et habitus de classe. Scolies, 1, s. 7-26.

Bourdieu, P. \& L.J.D. Wacquant (1992). An Invitation to Reflexive Sociology. Chicago: The University of Chicago Press.

Burke, K. (1984). Attitudes Towards History. Berkeley: The University of California Press.

Calhoun, C. (1995). Critical Social Theory: Culture, History, and the Challenge of Difference. Oxford: Blackwell.

Cookson Jr., P.W. \& C.H. Persell (1985). Chartering and Bartering: Elite Education and Social Reproduction. Social Problems, 33 (2), s. 114-129.

Domhoff, W.G. (1993) The Power Elite and the State. New York and Berlin: Aldine.

Durkheim, É. (1909) Sociologie religieuse et théorie de la connaisance. Revue de Métaphysique et de Morale, 1. November 1909, 17(6), s.733-758.

Durkheim, É. (1950): "Définition de l'État". I: Lecons de sociologie. Paris: Presses Universitaires de France.

Gerth, H. \& C.-Wright Mills (1946) From Max Weber: Essays in Sociology. Oxford: Oxford University Press.

Harrison, P.R. (1993) Bourdieu and the Possibility of a Postmodern Sociology. Thesis Eleven, 35, s. 36-50.

Levine, S.B. (1980) The Rise of American Boarding Schools and the Development of a National Upper Class. Social Problems, 28, April s. 63-94.

Marcus, G.E. (1991) Lives in Trust: The Fortunes of Dynastic Families in Late 20th-Century America. Boulder: Westview Press.

Mauss, M. (1989) Manuel d'etnographie. Bibliotheque Payot, Paris, 3. utg. s. 7.

Schwartz, M. (1987) The Structures of Power in America: The Corporate Elite as Ruling Class. New York: Holmes and Meier.

Useem, M. \& J. Karabel (1986) Educational Pathways to Top Corporate Management. American Sociological Review, 51, April, s. 184-200.

Useem, M. (1984): The Inner Circle: Large Corporations and the Rise of Business Political Activity in the U.S. and U.K.. New York: Oxford University Press.

Wacquant, L.J.D. (1990) Sociology as Socio-Analysis: Tales of "Homo Academicus". Sociological Forum, 5, s. 677-689.

Whitehead, A.N. (1948) Science and the Modern World, New York: New American Library.

Zweigenhaft, R.L. \& G.W. Domhoff (1991) Blacks in the White Establishment? A Study of Race and Class in America. New Haven: Yale University Press. 